\title{
Effect of Bypass Nutrients on pH and Water Holding Capacity of Goat Meat
}

\author{
S.R. Lende*, A.D. Deshmukh, A.P. Dhok, N.V. Kurkure, S.W. Bonde, \\ J.M. Chahande, S.B. Kawitkar, D.S. Raghuwanshi and K.P. Kharkar
}

Department of Animal Nutrition, Nagpur Veterinary College, Maharashtra Animal and Fishery Sciences University, Seminary Hills-440006, Nagpur, Maharashtra, India

*Corresponding author

Ke y w or d s
Kids, Bypass fat,
Bypass protein, $\mathrm{pH}$,
WHC, Concentrate
mixture

\section{A B S T R A C T}

Twenty four three months old kids were randomly divided into four groups considering their sex and body weight in such a way that each group carry three male and three female with non-significant difference in body weights between the treatment groups. Group T0 was fed with Green roughage + Dry roughage + Concentrate mixture, Group T1 was fed with Green roughage + Dry roughage + Concentrate mixture supplemented with bypass protein@ 2.5 percent of dry matter intake, Group T2 was fed Green roughage + Dry roughage + Concentrate mixture supplemented with bypass fat @ 2.5 percent of dry matter intake, Group T3 was fed with Green roughage + Dry roughage + Concentrate mixture supplemented with Bypass protein, Bypass fat in combination each @ 2.5 percent of dry matter intake.. It was observed that the $\mathrm{pH}$ values of the goat meat at the end of experiment were relatively same among all the treatments and as regards to water holding capacity of goat meat it was highest in combination group of bypass nutrients and was lowest in control group.

\section{Introduction}

The chevon is one of the most widely preferred and consumed meat in India. To meet the projected demand for goat meat, country has to almost double the existing goat population, which will be a challenging task considering the available resources including feed, fodder and grazing areas. Presently goat ensures livelihood to over five million households in India and this number would certainly increase as the goat provides future hope for better livelihood and income for more and more people living in agro- geo- climatic disadvantageous areas (Devendra, 2011). A proper nutrition input is necessary for maximum exploitation of the genetic potential. One of the major factor contributing to low productivity of goats in our country is non availability of nutrition as 
per the requirements. Adequate nutritional inputs should be provided as per the requirement of different physiological functions. To adopt suitable feed management practices, the goat flock has to be divided into different groups depending upon the physiological functions like growth, pregnancy and lactation over and above the maintenance (Bhatt and Khan, 2009).

In field condition, goats are largely dependent on grazing alone to meet their nutrient needs. However, grazing lands are shrinking and animals need to be provided with alternate feed resources to meet their nutrient requirements (Ravindra Kumar et al., 2017). Management of feed and fodder resources is crucial for the future development of goat production in the country. Therefore, concerted efforts are required to develop technology for enhancing animal productivity, besides increasing the productivity of fodder per unit area and utilization of the waste lands and newer non- conventional feed resources for goat production. Innovative research strategies need to be formulated to ameliorate impact of climate changes on health and productivity of animals.

Several nutritional technologies have been developed during the last couple of decades. However, most of these technologies are yet to be adopted on a large scale either by the industry or by the farmer, because of lack of interaction and efforts made to transfer feeding technologies to the field. Feeding of bypass nutrients has emerged as one of most important nutritional technology, which has potential application in the feed industry especially for growth of animal possessing higher genetic merit and for boosting up of milk production, wool production (Sanjay Kumar et al., 2015). Protected nutrients are the fractions of the nutrient, which gets fermented at a lower degree in the rumen, which becomes available at the lower part of the gastrointestinal tract for the subsequent digestion and absorption. In addition to this, the bypass nutrients impart a steady supply of nutrients in place of providing all the nutrients immediately with sudden bursts from easily soluble nutrients (Walli et al., 1995). At the beginning the concept of bypass nutrients was used for proteins, to describe the protein quality in ruminants, but subsequently this term has been extended to other nutrients such as carbohydrates as well as fats that could also escape rumen fermentation moderately and digested and absorbed in the small intestine. The concept of bypass nutrients is helpful not only for finer utilization of nutrients but also to decrease the ruminal fermentation losses thereby reducing the wastage of nutrients into the environment and thereby eco-friendly ruminant husbandry.

Feeding of by-pass protein generally results in an additional supply of amino acids to the host animal. In growing ruminants, the extra amino acids enhance growth of muscle tissues. In lactating animals acquiring insufficient energy from their diet, the surplus supply of amino acids compensates for the reduced supply of propionate (glucogenic precursor). This enhances glucose production in the liver and glucose supply to the mammary gland which triggers more lactose synthesis in the organ. Further, need to provide bypass protein to ruminants also arises in case of animals thriving only on poor quality roughages as sufficient quantities of microbial protein is not synthesized, as this process is an energy dependant process. However, it is essential to ensure that sufficient amount of rumen degradable protein $(50-60 \%$ of total crude protein) is supplied in the ration of these animals to maintain optimum rumen fermentation for better utilization of fibre.

Considering the significant importance of bypass protein and bypass fat on growth and meat quality, efforts were made to arrive at a 
complete package of feeding practices from day old to marketable age in goats for the improvement in body weight gain and meat quality on economical basis.

\section{Materials and Methods}

Twenty four three months old kids were randomly divided into four groups considering their sex and body weight in such a way that each group carry three male and three female with non- significant difference in body weights between the treatment groups. Group T0 was fed with Green roughage + Dry roughage + Concentrate mixture, Group T1 was fed with Green roughage + Dry roughage + Concentrate mixture supplemented with bypass protein @2.5 percent of dry matter intake, Group T2 was fed Green roughage + Dry roughage + Concentrate mixture supplemented with bypass fat @ 2.5 percent of dry matter intake, Group T3 was fed with Green roughage + Dry roughage + Concentrate mixture supplemented with Bypass protein, Bypass fat in combination each @ 2.5 percent of dry matter intake. The growing kids of each group were housed in pens with proper ventilation, flooring, having facility of feeding and watering. Health records were maintained throughout the experimental period. Recommended standards of hygiene, management, vaccination and deworming schedule were followed for all the experimental kids throughout the experimental period. Fresh drinking water was made available to the growing goats throughout experimental period. Carcass characteristics parameters were studied after slaughter of three goats from each group at the end of experimental period.

\section{Water holding capacity of meat}

The water holding capacity (WHC) was determined by the method as described by Wardlaw et al., (1973) with slight modifications. Twenty grams of minced meat sample was blended with $30 \mathrm{ml}$ chilled Nacl $(0.6 \mathrm{M})$ in centrifuge tube. The slurry formed was stirred for 1 minute. With the help of glass rod which was then held at $4^{0} \mathrm{C}$ for 15 $\min$.

Then the sample was centrifuged at $5000 \mathrm{rpm}$ for $15 \mathrm{~min}$. Water absorbed by meat was measured and expressed as WHC (\%).

\section{pH of goat meat}

The $\mathrm{pH}$ of the finely minced and homogenized sample was determined by method of Trout et al., (1992), wherein $50 \mathrm{ml}$ distilled water and 10 g. Sample was mixed and fine suspension was prepared. The $\mathrm{pH}$ was recorded using digital pH meter (Fig. 1).

\section{Results and Discussion}

The average per cent water holding capacity of meat in T0, T1, T2 and T3 groups were found to be $25.72 \pm 0.13,26.65 \pm 0.44$, $26.65 \pm 0.43$ and $27.52 \pm 0.26$ respectively. It was observed that the water holding capacity was highest in T3 group and lowest in T0 group. Percent water holding capacity of meat values was comparable in $\mathrm{T} 2$ and $\mathrm{T} 1$ group (Table 1).

The average muscle $\mathrm{pH}$ in $\mathrm{T} 0, \mathrm{~T} 1, \mathrm{~T} 2$ and $\mathrm{T} 3$ were found to be $5.33 \pm 0.03,5.37 \pm 0.09$, $5.47 \pm 0.09$ and $5.50 \pm 0.10$ respectively. It was observed that the $\mathrm{pH}$ values were relatively same among all the treatments. Variation among the treatment groups was nonsignificant. $\mathrm{pH}$ values were lower than 5.8 and within acceptable range (Gadekar, et al., 2011).

Generally meat with $\mathrm{pH}$ value more than 6 are not considered suitable for storage as it indicates favourable development of proteolytic microorganisms. 
Table.1 Average $\mathrm{pH}$ and $\mathrm{WHC}$ values of the experimental goats meat

\begin{tabular}{|c|c|c|c|c|c|}
\hline \multirow{2}{*}{$\begin{array}{c}\text { Carcass } \\
\text { Parameters }\end{array}$} & \multicolumn{4}{|c|}{ Treatments } & \multirow{2}{*}{$\begin{array}{c}\text { Statistical } \\
\text { Significance }\end{array}$} \\
\hline & T0 & $\mathbf{T 1}$ & $\mathbf{T 2}$ & T3 & \\
\hline pH & $\begin{array}{c}5.33 \\
\pm 0.03\end{array}$ & $\begin{array}{c}5.37 \\
\pm 0.09\end{array}$ & $\begin{array}{c}5.47 \\
\pm 0.09\end{array}$ & $\begin{array}{c}5.50 \\
\pm 0.10\end{array}$ & NS \\
\hline WHC (\%) & $\begin{array}{l}25.72^{a} \\
\pm 0.13\end{array}$ & $\begin{array}{c}26.65^{\mathrm{ab}} \\
\pm 0.44\end{array}$ & $\begin{array}{c}26.65^{\mathrm{ab}} \\
\pm 0.43\end{array}$ & $\begin{array}{l}27.52^{b} \\
\pm 0.26\end{array}$ & $5 \% \mathrm{CD}=1.11$ \\
\hline
\end{tabular}

Fig.1 Estimation of pH of goat meat

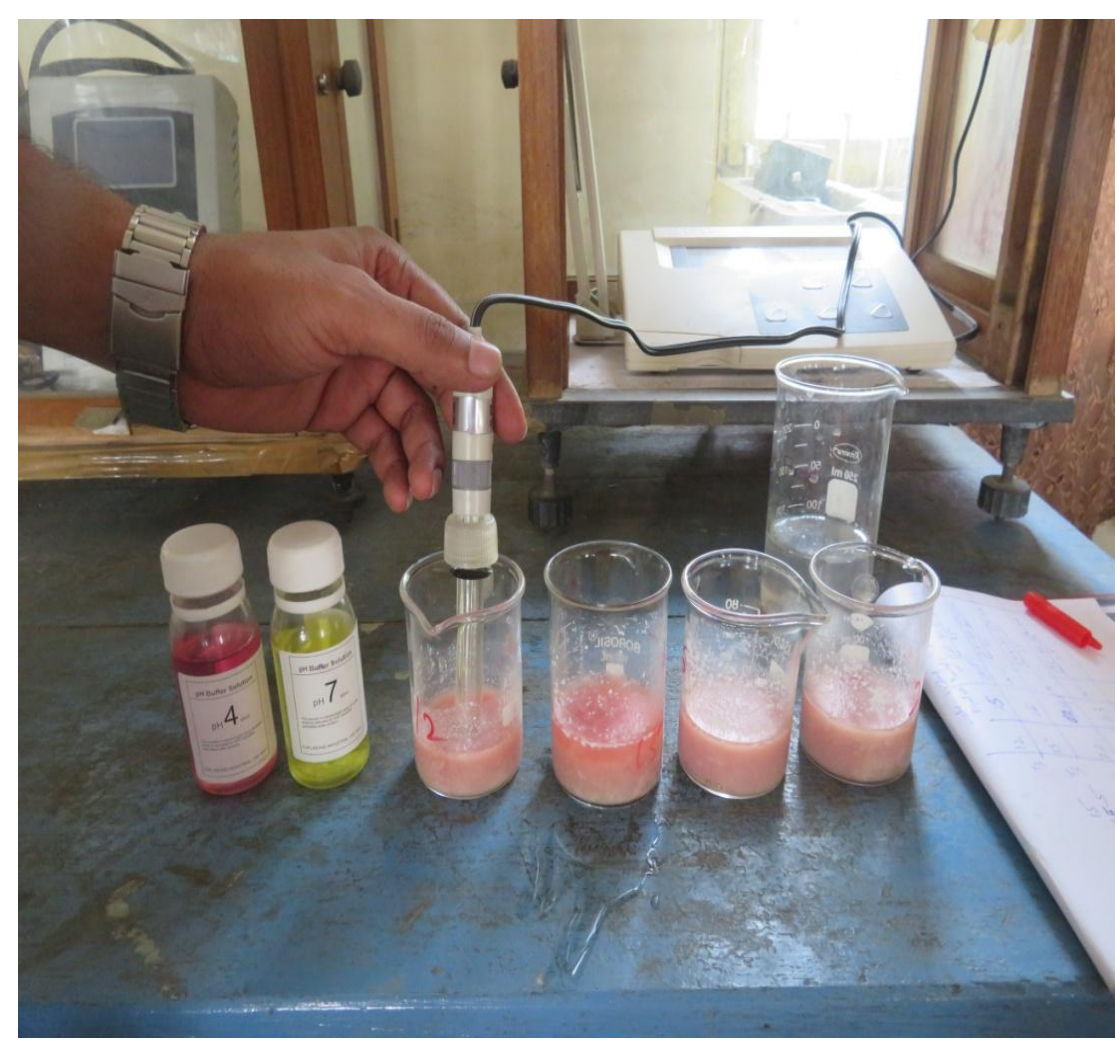

Results in the present study are in line with Najafi et al., (2012) who examined the effect of different types of fatty acids i.e., palm oil (high in 16:0 saturated fatty acid), soybean oil (high in 18:2 an omega-6 fatty acid) and fish oil (high in EPA 20:5 n-3 and DHA 22:6 n-3, omega- 3 fatty acid) in Mahabadi goat kids and found no difference $(\mathrm{p}>0.05)$ in muscle ultimate $\mathrm{pH}$ taken $24 \mathrm{~h}$ post slaughter.

Higher per centage of water holding capacity of meat in the present study might have resulted due to more fat deposition between muscle fibers and a lower muscle glycogen store (Hertog- Meischke et al., 1997).

\section{References}

Bhatt, P. N. and Khan B. U. 2009. Goat production, Studium Press (India) Pvt. Ltd., Ansari road, New Delhi-110002: 97

Devendra, Swarup 2011.Vision 2030, Director CIRG, Bytes \& Bytes, 
Bareilly: 3

Gadekar, Y. P., Shinde A. K., Bhatt R. S. and Khan S. A. 2011. Restructuring of carcasses of cull ewe by dietary incorporation of rumen protected fat during pre-slaughter fattening International journal of meat science. 1(2): 117-123.

Hertog- Meischke, M. J. A. den, R.J.L.M. van Laack and Smulders F.J.M. 1997. The water- holding capacity of fresh meat, Veterinary Quarterly. 19 (4): 175181.

Najafi M. H., Zeinoaldini S., Ganjkhanlou M., Mohammadi H., Hopkins D. L., Ponnampalam E. N. 2012. Performance, carcass traits, muscle fatty acid composition and meat sensory properties of male Mahabadi goat kids fed palm oil, soybean oil or fish oil. Meat Science. 92: 848-854.

Ravindra Kumar, Tripathi P. and Chaudhary U. B. 2017. Influence of feeding Azolla containing complete feed on performance of Goat kids. Indian J.Anim. Nutr. 34 (2): 229-232.

Sanjay Kumar, Rajni Kumari and Kaushalendra Kumar 2015. Feed supplements for livestock and poultry, Daya publishing house, New Delhi, India: 49-67.

Trout, E. S., Hunt M. C., Johnson D. E., Clans J. R., Castner C. L. and Kropf D. H. 1992. Characteristics of low fat ground beef containing texture modifying ingredients. J. Food Sci. 57 (1): 19-24.

Walli T. K., Garg M. R., Sampath K. T., Srivastava A., Singh G. P., Gill M. and Ibrahim M. N. M. 1995. Feeding of bypass nutrients to ruminants. Handbook for straw feeding systems (Kiran Singh and J B Schire, eds.), ICAR, New Delhi, India: 163-173.

Wardlaw, F. B., McCaskill L. H. and Acton J. C. 1973. Effect of postmortem muscle changes on poultry meat loaf properties. J. Food Sci. 38 (3): 421-423.

\section{How to cite this article:}

Lende, S.R., A.D. Deshmukh, A.P. Dhok, N.V. Kurkure, S.W. Bonde, J.M. Chahande, S.B. Kawitkar, D.S. Raghuwanshi and Kharkar, K.P. 2019. Effect of Bypass Nutrients on pH and Water Holding Capacity of Goat Meat. Int.J.Curr.Microbiol.App.Sci. 8(08): 1825-1829. doi: https://doi.org/10.20546/ijcmas.2019.808.215 